\title{
Policy of Telangana Government for Business Development
}

\author{
D.Thirumala Rao \\ Department of Commerce, Indian Institute of Management \& Commerce (IIMC), \\ Khairtabad, Telangana, India \\ E-Mail: dtrao1975@gmail.com
}

\begin{abstract}
This paper focuses on the Telangana State Industrial Policy and its scope for business development. The new Telangana State Industrial Policy is providing a framework which will not only make the industries to stabilize and competitive but also increases its scope for national and international investments in industrial sectors. The focus will be more on core manufacturing sectors with the creation of employment for urban and rural youth and adding values to existing skills emphasized at all stages. The policy is aiming at producing high quality goods at the most competitive price, which establishes "Made in Telangana - Made in India" as a brand with high global recognition. The corner stone of the policy is the Zero graft and Zero tolerance to corruption. The high expectations of the people of Telangana State about the job opportunities, infrastructure development, and uplift of backward sections of the society are the priorities Telangana State Government. This is possible only by the development of industries which in turn provides the job opportunities to youth and thereby increasing their standard of living. The new Telangana Industrial Policy will be the instrument through which the vision of the Telangana State Government will be translated into action. The Telangana State Industrial Policy aims at integrating the State's economy with global economy and to become world's "Industrial State".
\end{abstract}

Keywords: Adding Values, Skills, Global Recognition, Zero Graft and Zero Tolerance

\section{INTRODUCTION}

Telangana has been declared as a separate, $29^{\text {th }}$ State of the country. This status has been achieved after the sacrifices of many great people who struggled and fought for a separate State. The real success lies only when the State gets world recognition and develops economically without any crisis and can give hope for the future generations. The people of Telangana are with great hope and high expectations from the Telangana State Government for the job opportunities, education and infrastructural facilities, promotion of backward areas, balanced regional development, upliftment of weaker sections of the society. The people of Telangana are also aiming that the Government will provide maximum growth with optimum utilization of resources available within the State.

Industrialization holds the potential for fulfilling such dreams of the people of Telangana. The Vision for industrialization of Telangana is "Research to Innovation; Innovation to Industry; Industry to Prosperity". The industrial policy framework is driven by the slogan of "Telangana - Innovate, Incubate and Incorporate". The policy framework intends to provide a business regulatory environment where doing a business would be as simple as shaking hands. The industrial atmosphere will be very friendly to industrialists. Innovation and Technology will drive the industries of Telangana State. The Government of Telangana State realizes that industrial development requires large-scale private sector participation, with the government playing the role of a facilitator and a catalyst. The government is committed to provide a graft-free, hassle-free environment in which the entrepreneurial spirit of local, domestic and international investors will thrive to take up their industrial units in the state of Telangana as the preferred investment destination. To promote Telagana as the best investment destination for investors in India, the Telangana State Government is offering various incentives/benefits to all new industrial enterprises set up by SC, ST entrepreneurs in State, except in the Municipal Corporation limit of GHMC excluding existing Industrial Estates/Parks. Joint Venture industries and Women owned enterprises are encouraged by the Telagana State Government in its industrial policy.

\section{REVIEW OF LITERATURE}

Radha Krishna Mathur, Secretary, Union Ministry of MSME (2012) in an interview to the Confederation of Indian Industry (CII) on an overview of the challenges facing the development of MSME sector, and initiatives taken by Government of India, as covered in the article, "MSME sector nurtures Entrepreneurship, and meets Social Objectives", published in MSME Business deals Highlights in respect of a few of them are presented here. National Manufacturing Policy, National Manufacturing Competitiveness Programme, public procurement policy to promote and strengthen Micro and Small Enterprises, defence production policy and implications for MSMEs, impact of bleak global scenario on MSMEs, greater cooperation and collaboration between Indian MSMEs and their counterparts overseas,

P.M. Mathew (2012), in his article, "the Relevance of MSMEs", focuses on recent developments in the industrial sector, contribution of MSMEs, and prospects for growth during the Twelfth Plan period, along with directions in which MSMEs should move in future. The basic objective of the Twelfth Plan (2012-17) is "faster, sustainable and more inclusive growth", as indicated in the Approach Paper of the Twelfth Plan released by the Planning Commission in 2011. Among the thrusts meant for such an inclusive growth, faster creation of jobs, especially in manufacturing, is given a special focus. The strategy for 
the industrial sector under the Plan admits that performance of manufacturing is weak. The sector should grow at 11-12 per cent annually, compared to nearly 8 per cent at present, in order to create two million additional jobs per year. Improvements in the regulatory framework, reduction in transaction costs, transparency, and thrust on innovation are important items in the Plan's strategy kit. Productivity enhancement through the cluster mode, and better consultation and coordination in industrial policy making, are key imperatives.

D.Nagayya, et al., (1990) in the their publication, "Industrial Development of Madhya Pradesh: Status and Opportunities," present the findings of the study on reviewing the utilization of processes / technologies developed by national research and development organizations, and identify the scope for further utilization of such know-how in the integrated state of Madhya Pradesh, which has since been bifurcated into Madhya Pradesh and Chattisgarh. The investigation identifies projects for the benefit of entrepreneurs with varied backgrounds to set up resource-based industries in the small and decentralized industrial sectors. In the light of these investigations, an action strategy is presented for accelerating industrialization in the State with focus on transfer of technology. The study suggests prospective industries after a car eful assessment of the resource endowment, present utilization, and potential.

D. Nagayya, and P. Tirumala Rao (2010) in their article, "Development of Small and Medium Enterprises in Andhra Pradesh," present the small and medium enterprise scenario at the national level, review the progress of the sector in Andhra Pradesh district-wise, present incentives for industry and for enterprises in the ICT (Information and Communication Technology) sector in the State for 201015 , and indicate directions for the future with reference to Andhra Pradesh from an all India perspective. Districtwise data presented are in terms of number of units, fixed investment, and employment for five regions - Hyderabad region, rest of Telangana, Rayalaseema, North Coastal Andhra, and South Coastal Andhra. Data presented for the State and regions is from 1995 to 2010. District-wise particulars are given for 2004 a nd 2010, along with compound annual growth rate (CAGR) for 2010/2004. In all the three parameters, prominent position of Telangana region is clearly noticed in respect of micro and small enterprises.

D.D. Mali, (2001) in his edited publication, "Micro Enterprises Development - Policies and Programmes," covers the proceedings and papers presented in the workshop on Micro Enterprise Development organized by the Indian Institute of Entrepreneurship, Guwahati, highlighting various aspects of development of micro enterprises and entrepreneurship development. The book makes an important contribution to the literature on micro enterprises. The themes covered include the following: issues, policy perspectives, an alternative paradigm for micro enterprises, utilization of technologies available from research and development organizations, reforms in the industrial sector with focus on small enterprises, microfinance, self-help groups, credit and marketing support for micro enterprises, rural industrialization, selfemployment progrmmes, utilization of renewable sources of energy, entrepreneurship development, including promotion of entrepreneurship among women, role played by nongovernmental organizations in promoting entrepreneurship and micro enterprises, technology upgradation in the decentralized industrial sector covering handlooms and handicrafts, etc.

I.M.D. Little, et al., (1988) in their World Bank Research publication, "Small Manufacturing Enterprises: A Comparative Study of India and Other Economies," examine the Indian small enterprise development and policy in detail in an international context, and draw lessons for industrial policy in developing economies. To provide a comparison, the authors assess experiences with the development of small enterprises in several other economies, including Colombia, Indonesia, the Republic of Korea, Malaysia, Singapore, Taiwan, the United Kingdom, and the United States. The core of the book is an investigation of the claim that promotion of small enterprises has a special role in industrial policy, for example in facilitating the efficient use of labour and other factors of production. In addition to analyzing aggregate data from national sources, the authors make use of detailed surveys of the Indian shoe, soap, printing, machine tool, and metal casting industries. They analyze such issues as the relative factor intensity, productivity, and economic efficiency of small enterprises.

\section{RESEARCH GAP}

From the above review of literature it is analyzed that prominent position for industries should be given by the Telangana State by utilizing optimum resources for maximum benefit of people in Telangana. Industrial reforms should focus on small enterprises, microfinance, self-help groups, credit and marketing support for micro enterprises, rural industrialization, self-employment progrmmes, utilization of renewable sources of energy, entrepreneurship development, including promotion of entrepreneurship among women, role played by nongovernmental organizations in promoting entrepreneurship and micro enterprises, technology upgradation in the decentralized industrial sector covering handlooms and handicrafts. The new industrial policy should aim at making Telangana State industries global competitive and set up a platform for the future entrepreneurs. The industrial policy should be able to increase business opportunities in the Telangana Region.

\section{THE CORE VALUES OF TELANGANA STATE NEW INDUSTRIAL POLICY}

1. The Government regulatory framework shall facilitate industrial growth. 
2. Entrepreneurs will thrive in a p eaceful, secure and progressive business regulatory environment.

3. Industrial development will lead to massive creation of jobs for the youth.

4. Industrialization shall be inclusive and facilitate social equality.

5. Benefits of industrialization should reach margin and socially disadvantaged sections of the State.

6. Environment will be protected and potential impacts will be mitigated.

\section{OBJECTIVES OF THE STUDY}

1. To study the significant aspects of Telangana State new industrial policy.

2. To analyze the prospects of business in Telangana State.

\section{METHODOLOGY}

The study is based on Secondary Data. The secondary data has been collected from Journals, Magazines, Articles, News bulletins and Websites.

\section{A. Scope of the Study}

The scope is confined to the business prospects in Telangana Region only based on its new industrial policy (2015).

\section{B. Period of Study}

The period of study is taken between 2014 to 2017 only.

\section{Limitations of the Study}

1. The time period for the collection of data.

2. The study is based on the secondary data only.

\section{TELANGANA STATE NEW INDUSTRIAL POLICY 2015}

The Industrial Policy framework, which was passed in the Telangana Assembly in November, 2014, had promised to offer minimum inspection with maximum facilitation. The policy prescribed norms for giving permission to mega projects (Investment of Rs.200 crore \& above), large projects (Rs.10 crore - 200 crores) as well as small and medium project proposals. The Telangana Government has created a bank of Rs.1.5 lakh acres of land which can be facilitated for industrial purposes and transferred it to the Telangana State Industrial Infrastructure Corporation (TSIIC).A "Chasing Cell" has been formed to monitor the progress of various proposals, while presenting the features of policy. As per the new policy, Telangana State Industrial Project Approval and Self-Certification System (TS-iPASS), penal action will be taken on officials if there is any undue delay in processing applications. The mega projects will get approval within 15 days.

The features of the TS- New Industrial Policy are as follows:

1. TSIIC has made land bank 1.5 Lakh acres for industries.

2. $24 \times 7$ power supply to industries.

3. Maximum facilitation with minimum inspection.

4. A single window clearance system will be established

5. 15 sectors were identified for investment including IT, Hardware, Life Sciences, Automobiles, Gems and Jeweler.

6. $10 \%$ water reserved for industries from all irrigation sources.

7. A chasing cell will be set up in the Chief Minister's Office (CMO)

8. Entrepreneurs need to fill a single application form. The procedures are made simpler.

9. Industries categorized as Green (nonhazardous), Orange (less hazardous) and Red (more hazardous) will be accorded approval within 15 days, 21 days and 30 days.

10. Penal action against officials, if fail to give permission in time.

On the basis of secondary data provided it is analyzed that the Telangana State Government selected "Thrust Areas" for business in Telangana Region. Some of the Thrust Areas are taken for study, are as follows.

\begin{tabular}{|l|l|}
\hline \multicolumn{1}{|c|}{ Thrust Areas } & \multicolumn{1}{c|}{ Scope for Business } \\
\hline $\begin{array}{l}\text { IT Hardware, Electronics, } \\
\text { Communications and Bio-medical } \\
\text { Devices }\end{array}$ & $\begin{array}{l}\text { The Government of India has approved an IT Investment Region for Hyderabad as well as two } \\
\text { Electronic Manufacturing clusters. The large Health Industry in Telangana will support bio- } \\
\text { medical devices and medical equipments. }\end{array}$ \\
\hline $\begin{array}{l}\text { Bulk drugs, Vaccines, biological, } \\
\text { incubation centers and R \& D } \\
\text { facilities }\end{array}$ & $\begin{array}{l}\text { Hyderabad is the bulk drug and vaccine capital of the country. Leadership in formulations and } \\
\text { bulk drugs has to be maintained; new opportunities for life-saving drugs, new vaccines, and } \\
\text { biological have emerged. This is an urgent need to encourage this sector, especially in the } \\
\text { emerging life sciences areas. }\end{array}$ \\
\hline $\begin{array}{l}\text { Automobiles, Transport Vehicles, } \\
\text { Automobile components, Tractors } \\
\text { and Farm Equipments }\end{array}$ & $\begin{array}{l}\text { The automobile industry is important for any state. The Telangana State also aims at utilizing } \\
\text { opportunities from the investors to invest in these areas for growth and development in the } \\
\text { automobile industry in the future. }\end{array}$ \\
\hline FMCG and Domestic Appliances & $\begin{array}{l}\text { The growth rate of FMCG and Domestic appliances has been phenomenal, even when the } \\
\text { country's economy is low. Telangana should take the advantage of this area of business for the } \\
\text { economic growth of the State. }\end{array}$ \\
\hline $\begin{array}{l}\text { Textiles, Leather, Paper and Paper } \\
\text { products }\end{array}$ & $\begin{array}{l}\text { Telangana is a large producer of long staple cotton. The State has a strong base for Paper } \\
\text { industry. There is a tremendous demand for textiles and paper products as there is a growing } \\
\text { need in the market. }\end{array}$ \\
\hline
\end{tabular}


From the above table, it is analyzed that Telangana State Government through its policy, will focus on the above said thrust areas of business and will make Telangana State Industries as Globally recognized Industries.

A study has been done on some of the business opportunities in Telangana State. They are as follows:

1. Telangana Plans expanding Hyderabad Metro Rail from $72 \mathrm{Kms}$ to $250 \mathrm{kms}$ to grow to a Metropolis over next 20 years.

2. DongFang Electric Corporation (DEC) of China has come forward to setup 660-1000 $\mathrm{Mw}$ power generation plant in Telangana State.

3. Coca Cola plans Rs.1,000 crore plant in Telangana State.

4. ITC Plans Rs.3,500 crore Paper unit in Telangana.

5. Ikea - a Swedish Furniture Retail expected to open its first outlet in India at Hyderabad.

6. NTPC to setup 4,000 Mw Plant in Telangana State.

7. Hero set to open plant in Telangana State to invest Rs.1,500 crore to setup its plant, which will have the capacity to manufacture 15 lakhs two wheelers per year.

\section{CONCLUSION}

The Government of Telangana realizes that there is a great need for industrialization in Telangana State. It requires large scale participation by the private sector with the government playing a vital role of a facilitator and a catalyst in developing the State economy. The new industrial policy should act as an instrument through which the vision of the Telangana State should be achieved. The dreams and hope of the people of Telangana State can be realized only by materializing the task taken by the government, of industrialization. The manufacturing sector should be given priority which can lead to urban and rural youth development.

The Telangana State Government has conducted detailed studies and taken the advice of experts in various fields to identify the competitive advantages the State can have, given its, geographical locations, availability of raw material, available resources, skill-base, existing manufacturing practices and expertise and opening up of new opportunities.

Accordingly, Telangana State Government identified 14 sectors as thrust areas, investment in which will be accorded as per the priority basis over others. In the present study, 6 areas have been discussed.The new industrial policy of Telangana Government brought in revolutionary change in the industrial sector where it promises to become apex industrial hub of the country. The new Industrial Policy of Telangana will shine as an exemplar among the best in the world. 'Innovate in Telangana, Invest in Telangana, Incorporate in Telangana' should become the motto of the Industrialization in the State. It is strongly believed that with the new industrial policy in place, a growth rate of $4 \%-5 \%$ greater than the national growth rate in the manufacturing sector can be achieved.

The Telangana State Government welcomes aspiring industrialists, young entrepreneurs, investors to fulfill the aim of making the State as world's number one "Industrial State". Telangana Government should not only concentrate on the business development, but its priority should be on the infrastructural developments, roads, drainage system, clean and green Hyderabad particularly during rainy seasons. This will automatically leads to business growth.

\section{REFERENCES}

[1] IMD Little, Dipak Mazumdar and M. John Page, "Small Manufacturing Enterprises: A Comparative Analysis of India and other Economies", The World Bank, Washington, D.C. and Oxford University Press, New Delhi, 1988.

[2] D. Nagayya, et al., "Industrial Development of Madhya Pradesh: Status and Opportunities", National Institute of Small Industry Extension Training (NISIET), Hyderabad (Project sponsored by the Union Department of Science and Technology, New Delhi) 1990.

[3] D.D. Mali, "Micro Enterprise Development - Policies and Programmes", Indian Institute of Entrepreneurship (IIE), Guwahati, Assam, 2001.

[4] R.L. Hyderabad and S.G. Vibhuti, "Regional Disparities in the Development of Industrial Estates in Karnataka: A Case Study", GITAM Journal of Management, Vol. 6 No. 1, January - March, pp. 142-166, 2008.

[5] D. Nagayya and P. Tirumala Rao, "Development of Small and Medium Enterprises in Andhra Pradesh" in V. Hanumanta Rao, and S. Subba Rao (eds.), Industrial Development in Andhra Pradesh, 1956-2010, Past - Present - Future," The Federation of Andhra Pradesh Chambers of Commerce and Industry, Hyderabad, pp. 179-194, 2010.

[6] P.M. Mathew, "The Relevance of MSMEs," Yojana, Vol. 56 No. 1, January, pp. 60-63, 2012.

[7] Radha Krishna Mathur, "MSME Sector nurtures Entrepreneurship, and meets Social Objectives," MSME Business - Journal of Smal Business and Enterprise, Confederation of Indian Industry (CII) MSME Council, Vol. 2, No. 1, pp. 5-7, January, 2012.

[8] FAPCCI Review Weekly Journal of Federation of Andhra Pradesh Chamber of Commerce \& Industry, Vol. 14, No.51, December 17, 2014.

[9] www.aponline.gov.in/.../Industries\%20and\%20Commerce.

[10] www.telangana.gov.in/news/2014/12/17/state-industrial-policy. 